\title{
Archaeology, Architecture, and the Postcolonial Critique
}

\section{Nitschke, Jessica}

Springer

2021-02-01

Nitschke , J \& Lorenzon , M 2021, Archaeology, Architecture, and the Postcolonial Critique . in J Nitschke \& M Lorenzon (eds), Postcolonialism, Heritage, and the Built Environment : New Approaches to Architecture in Archaeology . SpringerBriefs in Archaeology, Springer, Cham , pp. 1-11 . https://doi.org/10.1007/978-3-030-60858-3_1

http://hdl.handle.net/10138/339516

https://doi.org/10.1007/978-3-030-60858-3_1

acceptedVersion

Downloaded from Helda, University of Helsinki institutional repository.

This is an electronic reprint of the original article.

This reprint may differ from the original in pagination and typographic detail.

Please cite the original version. 


\title{
Chapter 1
}

\section{Archaeology, Architecture, and the Postcolonial Critique}

Jessica L. Nitschke and Marta Lorenzon

\begin{abstract}
The built environment is central to human activity, serving as a stage upon which social activity takes place and is shaped. Built spaces not only reflect people's needs and beliefs but also affect their experiences. As the material manifestation of human values and histories, buildings are instruments of power and enforcers of hierarchy, but also serve as powerful sites for protest or resistance. Architecture and the built environment should then hold a central place in postcolonial archaeology and especially the decolonization movement, which seeks to rebuild the narrative of places through the empowerment of the historically underrepresented. However, despite the significance of the postcolonial critique for both archaeology and contemporary architectural theory, its impact has not been felt very deeply at the point where these two disciplines intersect. The first half of this introductory chapter summarizes the influence of postcolonial theory on the study of the built environment and explores its applicability in the analysis and interpretation of architecture from archaeological contexts. The second half summarizes the main themes of the volumes as well as the individual contributions themselves.
\end{abstract}

Keywords: archaeological theory; postcolonial archaeology; decolonisation; built environment; architecture 
The built environment is central to human activity, serving as a stage upon which social activity takes place and is shaped. Built spaces not only reflect people's needs and beliefs but also affect their experiences, playing a key role in the articulation of identity and sense of self (Archer 2005; Blier 1987). Buildings are in a continuous process of transformation and becoming, from the moment they are imagined through their various phases of construction, occupation, appropriation, remodeling, recycling, abandonment, and destruction (Segaud 2010; Lawrence-Zuniga 2001). As a culmination of countless small actions involved in creating, inhabiting, and maintaining space, the built environment presents a dynamic repository of information on invisible actors across time, which is in part why architecture has long been one of the "cornerstones" of archaeology (Bille and Sørenson 2016: 4).

As the material manifestation of human values and histories, buildings are instruments of power and enforcers of hierarchy. Architecture has been (and still is) used by the wealthy and ruling classes to impose order, manipulate identities, and control social relationships (Yeoh 2003; Coslett 2019; Weizman 2012). At the same time, built structures-whether monumental or modest, fixed or ephemeral — can serve as a powerful symbol or medium for protest and resistance. Constructed spaces are "sites of assertion, contestation, and subversion of difference" (Hosagrahar 2012: 82); as such, the application of the postcolonial critique to the built environment is both natural and essential.

Indeed, over the last thirty years or so, there has emerged within the fields of architectural theory and urban studies a rich body of research embracing the postcolonial critique, which we broadly define here as the critical examination of the cultural and ideological legacies of colonialism and imperialism (Sidaway 2000: 594; Liebmann 2008: 2). This embrace has been 
facilitated by the increase of anthropologically-informed theoretical approaches to architecture and space since the mid-to-late $20^{\text {th }}$ century, which have tried to steer the field away from simply focusing on the aesthetic or technical characteristics of architecture and towards viewing buildings as social objects (Buchli 2013; Segaud 2010; Amerlinck 2001; Ingold 2000; Rappaport 1969). A concerted effort has been made to open up urban histories to diverse viewpoints, to "rethink ... the connection between production, power relationships, architecture and urbanism" (Loo 2017: 631). The postcolonial critique has provided architectural historians and theorists with frameworks allowing them to deconstruct traditional Eurocentric conceptions of architecture; challenge the notion of a singular Western modernity; come to terms with how design is combined with policy to reinforce relationships of power; highlight subordinated spaces and agency; and dismantle problematic dichotomies such as Western-nonWestern, traditionalmodern, colonizer-colonized (Hosagrahar 2012; King 2003; Nalbantoğlu and Wong 1997; Kusno 2000; Akcan 2014; James-Chakraborty 2014).

As for archaeology, the field has undergone its own sustained period of critical selfreflection with respect to its origins and complicity in the perpetuation of colonial power structures (Effros and Lai 2018; Lydon and Rizvi 2010). The postcolonial critique has provided the means for archaeologists to confront how core intellectual aspects of the discipline, such as the ordering of the past and conceptions of cultural identity, are enmeshed in modern colonial systems and nationalism (Croucher 2010; Trigger 1984). This self-awareness has intensified in recent years, as archaeologists have increasingly recognized the "deeply colonial, racist, and sexist epistemology of our field" (Rizvi 2015: 156). The postcolonial critique now has an established place within archaeological theory and practice, as scholars increasingly rely on postcolonial discourse to deconstruct Western traditions of knowledge that have produced 
distorted narratives of human history and culture (Johnson 2019; Gosden 2012; van Dommelen 2011).

Imperialism, (neo)colonialism, racism, and sexism are of course still very much present in the world, and archaeologists, in their role as intermediaries between the materiality of the past and human society in the present, have begun to think more critically about the social impact of their individual actions and of the field as a whole. Some archaeologists and organizations (e.g. the World Archaeological Congress) are pushing the field beyond epistemological awareness towards a decolonization of the discipline, asking how we can undo or correct the harm caused by colonialism and the knowledge systems it produced (Harris and Cipolla 2017: 180). Decolonization in archaeology focuses on supporting indigenous communities and individuals in expressing their own perspectives on materiality, developing their own archaeological practices, and asserting their ownership with regards to knowledge, objects, and land (Sabloff 2016; Wynne-Jones and Fleisher 2015). Although "decolonization” is sometimes used interchangeably with "postcolonialism", it is important to acknowledge that decolonization is not simply a metaphor or analytical framework, but rather an intrinsically political action concerned with redress and social justice (Rizvi 2019; Petti et al. 2013).

Architecture and the built environment should hold a central place in postcolonial archaeology and especially the decolonization movement, which seeks to rebuild the narrative of places through the empowerment of the historically underrepresented. However, despite the significance of the postcolonial critique for both archaeology and contemporary architectural theory, its impact has not been felt very deeply at the point where these two disciplines intersect. There remains a lack of focused studies in archaeological literature that use postcolonial approaches to rethink methodologies and frameworks employed in the study of architecture, 
which is often treated separately from other categories of material culture (Lucas 2016: 105). Archaeology emerged out of European antiquarian interest in the aesthetic qualities of ancient ruins, and the methods and attitudes towards architecture that developed then remain strong in the field today. Analyses are still based on neat typologies and strictly delineated categories that have their origins in Western colonial ordering of space and place (Bille and Sørenson 2016). Enlightenment attitudes about technology vis-à-vis progress continue to influence archaeological approaches and attitudes towards landscape and building (Porr 2018). In colonial and intercultural contexts in particular, evolutionary and diffusionist models of culture continue to be used to guide interpretations (Croucher 2010). There is still a tendency to rely on false dichotomies such as center-periphery, West-East, and colonizer-colonized, which oversimplify entangled cultural dynamics over time.

These shortcomings reflect the reality that we are "traveling towards a post-colonial archaeology rather than having arrived there" (Gosden 2012: 259). The postcolonial critique will continue to shape archaeology in significant ways, as researchers try to deal with the understanding that their own biases, training, and privilege are just as much a variable in archaeological analysis as is the survival of the record (Rizvi 2015: 161). In pushing the discourse forward, especially with regards to the built environment, it is worth reflecting on some of the challenges of applying the postcolonial critique to the study of built spaces of the past.

One challenge lies in the primary methodology used to document and interpret built spaces of the past, namely drawing and typologies. Two-dimensional plans and sections are the bread-and-butter of fieldwork and publication, but this method of observation and representation tends to isolate architecture and treat it as a static object, taking it out of its time, place, and 
human context (Bille and Sørenson 2016: 7). The focus on ground plans comes at the expense of equally important aspects for understanding not only the nature of the building structure (e.g. construction materials, building methods, roofing, floor materials, wall coverings, furnishings) but also the experiential, i.e. how people interact with the space. Ground plans and elevation drawings often stand in for physical buildings in reports and publications, becoming the basis for typological categories. As a result, discussion of function and meaning of a building can become fixed in an artificial way. To successfully apply the postcolonial critique to the study of the built environment in archaeology, it will be necessary to transform traditional practices of description, representation, and analysis in ways that will allow us to more easily conceptualize the full phenomenology of built spaces in the past.

The problems of representation and interpretation of the built environment in archaeology have not gone unacknowledged. There have been efforts to bring a more anthropological approach to constructed spaces in archaeology, especially since the 1990s, when a number of studies emerged seeking to confront the reality that "archaeologists have not been very successful in formulating a theory of architectural interpretation" (Kamp 1993: 293; see also Steadman 1996; Moore 2003). This work has reframed architecture as a dynamic rather than static form of materiality; highlighted the symbolic importance of not just building but also space; emphasized the need to bring more attention to process; and brought focus on the analysis of materials not just for their technical role but also their social meaning (Parker Pearson and Richards 1994; Scattolin et al. 2009; Ingold 2013; Bille and Sørenson 2016; DeLaine 1997). Progress, however, has been somewhat slower more recently (Bille \& Sørenson 2016: 4). Even with the rise of digital technologies that help us visualize ancient built spaces in more experiential ways, we still lack the theoretical frameworks for how to incorporate such tools and 
(more importantly) evaluate the effectiveness, authenticity, and ethics of such representations (Pujol-Tost 2019; Richter et al. 2013).

Another way in which the application of postcolonial approaches to the study of the buildings of the past is complicated is the place of these structures and spaces in the present. Whether uncovered through excavation or standing aboveground for millennia, built spaces often have long histories of use and adaptation within changing social, natural, and urban landscape(s). We must acknowledge the reality that not all periods of use, repair, or remodeling of a given building or space are of equal interest to archaeologists or heritage managers. The decision to give primacy to certain material pasts can be ideologically or economically motivated, and there is often an inherent contradiction between conservation of historical spaces and urban development. The question of which built space is to preserved, cherished, and/or turned into a tourist attraction, and which is to be dismantled to discover what lies below or built over for the sake of modernity, is complicated and fraught, with repercussions for the well-being and identity of local communities (Harrison and Hitchcock 2005; Abu Al Haija 2012; Loo, this volume).

Historical buildings and places have complex meanings in modern social imaginaries, a complexity which can be lost in broad application of the label "heritage". Heritage itself is a Western concept, the meaning of which is fluid and constituted through complex processes (Graham et al. 2005). Places of heritage are frequently contested; one person's heritage can be the symbol of another's oppression (Abdelmonem 2017; Lupuwana and Naidoo, this volume). Western notions about so-called universal or world heritage have been and continue to have an oversized influence on what is preserved and what is changed in historical spaces, often in ways that are at odds with the interests of current inhabitants, especially in communities lacking economic or political power (Coslett 2019; Odiaua 2013; Hosagrahar 2012). Applying the 
postcolonial critique to architecture in archaeology means recognizing that archaeologists cannot separate themselves or their work from the heritagizing of urban and rural landscapes, nor ignore the question of who benefits and for what purpose (Yeoh 2001). Archaeological narratives of space and place provide meaning and lend authority, shaping public perceptions now and in the future. As public intellectuals, archaeologists have responsibilities not just to their research question or to the publication of results, but also to the reception of their analyses and to the communities they work in, even if these perspectives challenge archaeologists' academic knowledge base (Johnson 2019: 255).

If the aims of postcolonial archaeology are to dismantle colonial bias in our research and to empower subordinated voices and perspectives, we must continue to rethink our analytical frameworks and methods for investigating ancient structures as well as reflect more critically about the potential of our work to affect communities and shape public perceptions of the past. The present volume tries to do just that with a series of essays written by scholars from six continents, each presenting a case study examining the ways in which we describe, analyze, and interact with the built spaces of the past in the present or how the contemporary built environment is used to remember, modify, or erase the past. The goal of this collection is to connect and complement existing anthologies in three related areas: architecture in archaeology, postcolonial archaeology, and global architecture and urban studies (e.g. Bille and Sørenson 2016; Wynne-Jones and Fleisher 2015; Lydon and Rizvi 2010; Hamilakis and Duke 2007; Coslett 2019; Lewi and Peckham 2017; Bishop et al. 2003).

The SpringerBriefs in Archaeology Series is meant to provide a snapshot of a topic, and therefore the restricted length of format means that only a limited selection of case studies can be included here. We nonetheless wanted to present something that encourages global comparisons 
and brings together the connected threads of intellectual discourse taking place in different but related fields, as it has long been recognized that in order for the archaeology of architecture to progress, multidisciplinary and comparative approaches are necessary (Steadman 1996: 77; see also Bille and Sørenson 2016). Accordingly, the chronological, geographical, and disciplinary range of the case studies presented here is purposefully wide. While the intended audience of this collection are readers who identify (at least in part) as archaeologists, we have included essays by professionals in the fields of architectural history, urban studies, and conservation in addition to archaeology because we believe their analyses offer archaeologists fresh perspectives on extracting and interpreting social and cultural information from the built environment. The hope is that these essays provide inspiration to think critically about the ways in which the built environment of the past continues to shape identities and social relationships today. While this collection in no way claims to address all sides or even a small portion of the issues raised, it is hoped that these essays show how continuing engagement with the postcolonial critique can help us pursue more inclusive, sensitive, and nuanced interpretations of the built environment of the past.

In the essays that follow, many issues are touched upon, but there are three broad interconnected themes that draw the different contributions together. The first group of essays is primarily concerned with recovering the perspectives of groups traditionally excluded from historical and archaeological narratives of architecture - people who might be termed the "subaltern" in postcolonial terminology. As Trouillot notes in his introspective critique of the historical process, "any historical narrative is a particular bundle of silences." (Trouillot 1995: 27). Accordingly, this group of essays reflects on how subordinated people - including the colonized (Frey, Porr), women (Lorenzon), migrants (Beeckmans), and builders (Frey)—speak 
through architecture and built spaces. The second group of essays, while still taking the perspective of subordinated peoples as a central concern, are focused on the use (and abuse) of the past in the present, exploring the intersection of power, building, and identity in postcolonial landscapes. This group of essays feature case studies concerning recent heritage controversies and initiatives, some that perpetuate colonial hierarchies and Eurocentric viewpoints (Nitschke, Lupuwana and Naidoo), and others that try to reconcile colonial pasts with contemporary identities for the purpose of healing and sustainability (Loo; Pereira and Heinsen). A third theme that recurs through several of the contributions in both groups is community and public engagement. The most positive outcomes that occur in the case studies described in this volume came about as a result from collaboration within communities. Such interactions not only have the effect of challenging our intellectual assumptions about buildings, process, and identity, but can also assist in developing positive connections between communities, heritage, and the contemporary urban landscape, contributing to a greater social benefit.

Marta Lorenzon begins by confronting a long-running bias in traditional archaeological approaches to architecture, namely gender. As part of the embrace of postcolonial approaches in archaeology, gender theory is thriving in contemporary archaeological discourse (Ströbeck 2010). However, traditional attitudes associate the construction and design of buildings with men. While the identity of designers and laborers is often hard to trace in the archaeological record, Lorenzon shows what the fields of building archaeology and ethnoarchaeology have to offer as a tool for detecting and understanding the presence of invisible agents, in this casewomen. Through her survey of ethnoarchaeological studies of mudbrick architecture in Africa, Lorenzon points a way forward for thinking more critically about social roles broadly and gender roles specifically in building processes and building as a trade, advocating for a type of fieldwork 
in which archaeologists actively engage with local communities who often have unique knowledge and expertise.

Jon Frey continues with the challenge of detecting the invisible agents behind architecture through his reconsideration of a sixth-century Byzantine fortification wall that spanned the Isthmus of Corinth in Greece, erected as part of imperial efforts to "protect" the inhabitants from the perceived threats from northern invaders. In his analysis, Frey shifts the perspective from that of imperial purpose to that of the builders and inhabitants and considers the impact of this imperially-imposed wall on local cultural perceptions of the landscape. His approach builds on recent work in Roman architecture that has pushed back against older traditions of scholarship that perceives ancient monuments as ideal structures, perfectly conceived and executed. Frey argues that certain aspects of the wall's archaeological remains that have long puzzled observers should be read as evidence of ambivalence and dissent by the local community towards this "defensive" structure during its construction and a re-appropriation of space after its completion.

For archaeologists, imagining how spaces were used apart from and in addition to how they may have been intended, particularly by those who are hidden in the material record, is an ongoing challenge. Luce Beeckmans explores the phenomenon of intentional invisibility and the built environment through her ethnographic study of African diaspora populations in Ghent, she shows us in detail how a $19^{\text {th }}$ century terrace house has been invisibly (at least from the outside) transformed by political refugees to serve multiple functions: shop, home, restaurant, bar, and hair salon. The manipulation of this space has been done in such a way so as to respond to the needs of a dispossessed migrant community trying to retain their sense of identity and successfully exist within a new setting with different traditions about urban, public, and private 
space. Beeckmans' analysis is a reminder of how tenuous perceived connections between form and function in architecture can be and how dynamic urban space can be even when façades seem unchanging.

Martin Porr presents to us the case of agents who are not necessarily invisible, but whose traditions regarding the built environment have long been ignored or misunderstood: Aboriginal Australians. The perceived lack of a "proper" built environment was used by European settlers to legitimize their acts of dispossession in Australia. While numerous scholars have brought attention to Aboriginal built structures and settlements in order to disprove characterizations of Australia as empty and undeveloped, Porr suggests that such efforts, rather than countering colonial narratives, actually validate colonial frameworks of analysis that equate "civilized" society with certain types of built structures. What is needed, Porr argues, is to challenge the premise of the framework itself. Through a discussion of different types of Aboriginal interventions in the landscape of Australia, Porr demonstrates that social complexity need not be accompanied by urban densification, encouraging us to think more holistically about social constructions of space. He shows how Aboriginal Australian philosophies provide different perceptions of the relationship between humans and environment which necessitate rethinking analytical categories such as "building" and "structure".

Jessica Nitschke continues unpacking the negative legacy of western intellectual traditions in her case study on the reproduction of the Monumental Arch from Tadmor-Palmyra in Syria in Trafalgar Square in 2016, following the destruction of the original by the Islamic State in 2015. She argues that not only is the replica a poor representative of the original, its display and narrative as a triumphalist relic of Roman rule perpetuates old characterizations of Near Eastern cities in a way that is fundamentally neocolonial. The project was a missed chance 
to illuminate the debt of Western architecture to ancient Near Eastern builders, whose contribution to the global history of architecture is underappreciated. She notes that the postcolonial critique, although widely embraced in some areas of Mediterranean archaeology, has failed to make an impact on public perceptions of architecture in the Roman empire, which is still unfortunately viewed and taught through the lens of Greek and Roman culture.

Vuyiswa Lupuwana and Navashni Naidoo continue the discussion of the relationship between academics and public perception of monuments, space, and the past through their discussion of colonial heritage and modern development in Cape Town. They begin with the \#RhodesMustFall movement as a window into how architecture and monuments continue to stand in the way of post-apartheid healing and social equality in South Africa. Arguing that archaeologists and historians have a key role to play in negotiating heritage and space, Lupawana and Naidoo provide an analysis of the controversial rescue excavation of the $17^{\text {th }}$ century Prestwich Street burial ground central Cape Town and the subsequent failure to respectfully memorialize graves and curate the remains. The Prestwich Street debacle is a text-book example of the confrontation of heritage and modern development, and Lupuwana and Naidoo's autopsy of the affair highlights intertwined issues of class, race, identity, heritage, and economy, ending with a call for archaeologists to use their positions of privilege to help silenced communities reimagine and re-appropriate the materiality of the colonial world.

In the pressure to achieve "progress" in postcolonial cities, there is a constant tension between development and heritage, which is itself contested in larger power struggles that often have an ethnic or religious element at play. Yat-Ming Loo explores these conflicts in the case of case of Kuala Lumpur in Malaysia, where the state, in their pursuit of national identity based on Malay-Muslim cultural, has actively suppressed the status, culture, and identity of ethnic 
minorities who have been a part of Kuala Lumpur since its founding. Loo details how the Chinese community has successfully transformed the historical Chinese cemeteries into a Heritage Park in order to preserve places in the landscape of old Kuala Lumpur that not only function as monuments to the Chinese community's role in the history of Kuala Lumpur but also serve as sites for maintaining a sense of belonging in the city and nation. By including cemeteries of other ethnic groups and therefore imbuing the Heritage Park with a multicultural identity, these community efforts have promoted an alternate interpretation of Malaysian national identity to counter the ethno-culturally restrictive one put forward by the state.

Going beyond cities to the countryside, Magdalena Pereira Campos and Cristian Heinsen Planella demonstrate how conservation, government support, and community organization can come together to preserve heritage and achieve sustainable progress in postcolonial contexts within rural landscapes. The region of Arica y Parinacota in northern Chile has been heavily affected by the legacy of colonialism and economic globalism, and the resulting migration of Indigenous people to cities is unsustainable and problematic. Pereira and Heinsen outline their efforts to create economic opportunity and social cohesion through the restoration of historical churches in the countryside of this region, combining architectural preservation, heritage management, and ancestral knowledge. These churches reflect a building type and cultural practice that were introduced by colonial rule but were adopted and adapted over the long term by the indigenous inhabitants. As a result, the churches, in terms of both their material form and the rituals surrounding them, became a locus of social life and type of heritage unique to the region. Their preservation is key to maintaining the identity of the Indigenous inhabitants and their traditional connection to the landscape. Pereira and Heinsen show that if we wish to successfully combine postcolonialism with heritage, archaeology, and the built environment to 
bring about an equitable and sustainable future, then there must be as much focus on small communities as there is on urban centers.

\section{References}

Abdelmonem, M. G. (2017). Architectural and urban heritage in the digital age: Dilemmas of authenticity, originality and reproduction. International Journal of Architectural Research: ArchNet-IJAR, 11(3), 5-15.

Abu Al Haija, A. H. (2012). Jordan: Guidelines for urban and architectural heritage conservation: Umm Qais case study. International Journal of Architectural Heritage, 6, 62-85.

Akcan, E. (2014). Postcolonial theories in architecture. In E.G. Haddad \& D. Rifkind (Eds.), $A$ Critical History of Contemporary Architecture (1960-2010) (pp. 115-136). London: Ashgate.

Archer, J. (2005). Social theory of space: Architecture and the production of self, culture, and society. Journal of the Society of Architectural Historians, 64(4), 430-433.

Amerlinck, M. J. (Ed.). (2001). Architectural anthropology. Bergin \& Garvey.

Bille, M. and Sørenson, T. F. (Eds.). (2016). Into the fog of architecture. In M. Bille and T. F. Sørenson (Eds.) Elements of Architecture: Assembling archaeology, atmosphere and the performance of building spaces (pp. 1-29). New York: Routledge.

Bishop, R., Phillips, J., and Yeo, W.-W. (Eds.) (2003). Postcolonial urbanism: Southeast Asian cities and global perspectives. New York: Routledge. 
Blier, S. P., (1994). The anatomy of architecture: Ontology and metaphor in Batammaliba architectural expression. University of Chicago Press.

Buchli, V. (2013). An anthropology of architecture. London: Bloomsbury.

Coslett, D.E. (Ed.). (2019). Neocolonialism and built heritage: Echoes of empire in Africa, Asia, and Europe. London: Routledge.

Croucher, S. K. (2010). Cultural identities and colonial and postcolonial archaeologies. In J. Lydon \& U. Rizvi (Eds.), Handbook of postcolonial archaeology (pp. 351-364). Walnut Creek: Left Coast Press.

DeLaine, J. (1997). The baths of Caracalla: A study in the design, construction, and economics of large-scale building projects. Portsmouth, R.I.: Journal of Roman Archaeology.

Effros and Lai (2018) Introduction: The global reach of imperial and colonial archaeology. In B. Effors and G. Lai (Eds.), Unmasking ideology in imperial and colonial archaeology: Vocabulary, symbols, and legacy (pp. xxi-xxxi). Los Angeles: Cotsen Institute of Archaeology Press.

Gosden, C. (2012). Postcolonial archaeology: Issues of culture, identity, and knowledge. In I. Hodder (Ed.), Archaeological theory today (pp. 251-66). Second Edition. London: Blackwell.

Graham, B., Ashworth, G. J. and Tunbridge, J. E. (2005). The uses and abuses of heritage. In G. Corsane (Ed.), Issues in Heritage, Museums and Galleries: An Introductory Reader (pp. 28-40). London: Routledge.

Harris, O. J. T. and Cipolla, C. N. (2017). Archaeological theory in the new millennium: Introducing current perspectives. Abingdon, Oxon: Routledge. 
Harrison, D. and Hitchcock, M. (Eds.). (2005). The politics of world heritage: Negotiating tourism and conservation. Clevedon: Channel View Publications.

Hamilakis, Y. and Duke, P. (Eds.), (2007). Archaeology and capitalism: From ethics to politics. Walnut Creek, CA.: Left Coast Press.

Hosagrahar, J. (2012). Interrogating difference: Postcolonial perspectives in architecture and urbanism. In C. Crysler, S. Cairns, H. Heynen (Eds.), The Sage Handobook of Architectural Theory (pp. 70-84). London: SAGE Publications.

Ingold, T. (2000). The perception of the environment: Essays in livelihood, dwelling and skill. London: Routledge.

Ingold, T. (2013). Making: Anthropology, archaeology, art and architecture. Abingdon, Oxon: Routledge.

James-Chakraborty, K. (2014). Beyond postcolonialism: New directions for the history of nonwestern architecture. Frontiers of Architectural Research, 3(1), 1-9.

Johnson, M. (2019). Archaeological theory: An introduction. Hoboken, N.J.: Wiley-Blackwell.

Kamp, K. A. (1993). Towards an archaeology of architecture: Clues from a modern Syrian village. Journal of Anthropological Research, 49(4), 293-317.

King. A.D. (2003). Actually existing postcolonialisms: Colonial urbanism and architecture after the postcolonial turn. In R. Bishop, J. Phillips, and W.-W. Yeo (Eds.), Postcolonial urbanism: Southeast Asian cities and global processes (pp. 167-183). New York: Routledge.

Kusno, A. (2000). Behind the postcolonial: Architecture, urban space, and political cultures in Indonesia. London: Routledge. 
Lawrence-Zúñiga, D. (2001). From Bourgeois to modern: Transforming houses and family life in rural Portugal. In M.-J. Amerlinck (Ed.), Architectural Anthropology (pp. 171-200). Westport, CT: Bergin \& Garvey.

Lewi, H. and Peckham, A. (2017). The architecture of globalization and its discontents. The Journal of Architecture, 22(4), 629-630.

Liebmann, M. (2008). Introduction: The intersections of archaeology and postcolonial studies. In M. Liebmann and U. Z. Rizvi (Eds.), Archaeology and the postcolonial critique (pp. 1-21). Plymouth, U.K.: AltaMira.

Loo, Y. M. (2017). Towards a decolonisation of architecture. The Journal of Architecture, 22(4), 631-638.

Lucas, G. (2016). Building lives. In M. Bille and T. F. Sørenson (Eds.) Elements of Architecture: Assembling archaeology, atmosphere and the performance of building spaces (pp. 105120). New York: Routledge.

Lydon, J. and Rizvi, U. Z. (Eds.), (2010). Handbook of postcolonial archaeology. Walnut Creek, CA: Left Coast Press.

Moore, J. (2003). Archaeology in search of architecture. In J. Papadapoulos and R. Leventhal, Theory and practice in Mediterranean Archaeology: Old World and New World perspectives (pp. 235-246). Los Angeles: Cotsen Institute of Archaeology.

Nalbantoğlu, G. B. and Wong, C. T. (Eds.) (1997). Postcolonial space(s). Princeton: Princeton Architectural Press.

Odiaua, I. (2013). Les enjeux et les voies de la conservation et de la «patrimonialisation» des architectures anciennes du Mali et du Nigéria: Djenné, Kano, Sukur et Ushafa. Afrique: Archéologie \& Arts, 9, pp.121-124. 
Parker Pearson, M. and Richards, C. (Eds.) (1994). Architecture and order: Approaches to social space. London: Routledge.

Petti, A., Hilal, S., \& Weizman, E. 2013. Architecture after revolution. Berlin: Sternberg Press.

Porr, M. (2018). Country and relational ontology in the Kimberley, Northwest Australia: Implications for understanding and representing Archaeological evidence. Cambridge Archaeological Journal, 28(3), 395-409.

Pujol-Tost, L. (2019). Did we just travel to the past? Building and evaluating with cultural presence different modes of VR-mediated experiences in virtual archaeology. Journal on Computing and Cultural Heritage, 12(1), 2:1-2:20.

Rapoport, A. (1969). House form and culture. Englewood Cliffs, N.J.: Prentice-Hall.

Richter, A.M., Petrovic, V. Vanoni, D. Parish, S. M., Kuester, F. and Levy, T. E. (2013). Digital archaeological landscapes replicated artifacts: Questions of analytical phenomenological authenticity ethical policies in cyberarchaeology. 2013 Digital Heritage International Conference (DigitalHeritage), Marseille, pp. 569-572.

doi: 10.1109/DigitalHeritage.2013.6744826

Rizvi, U. (2015). Decolonizing archaeology: On the global heritage of epistemic laziness. In O. Khleif (Ed.) Two days after forever: A reader on the choreography of time (pp. 154-63). Berlin: Sternberg Press.

Rizvi, U. (2019). Archaeological encounters: The role of the speculative in decolonial archaeology. Journal of Contemporary Archaeology, 6(1), 154-167.

Sabloff, J. A. (2016). Archaeology matters: Action archaeology in the modern world. New York: Routledge. 
Scattolin, M.C., Cortés, L.I., Bugliani, M.F., Calo, C.M., Domingorena, L.P., Izeta, A.D., and Lazzari, M. (2009). Built landscapes of everyday life: a house in an early agricultural village of north-western Argentina. World Archaeology, 41(3), 396-414.

Segaud, M. (2010). Anthropologie de l'espace: habiter, fonder, distribuer, transformer. Armand Colin.

Sidaway, J. (2000). Postcolonial geographies: an exploratory essay. Progress in Human Geography, 24(4), 591-612.

Steadman, S. (1996). Recent research in the archaeology of architecture: Beyond the foundations. Journal of Archaeological Research 4(1), 51-93.

Ströbeck, L. (2010). Gender and Sexuality. In J. Lydon \& U. Z. Rizvi (Eds.). Handbook of Postcolonial Archaeology (pp. 327-350). Walnut Creek: Left Coast Press.

Trigger, B.G. (1984). Alternative archaeologies: nationalist, colonialist, imperialist. Man, 19, $355-70$.

Trouillot, M.-R. (1995). Silencing the past: Power and the Production of history. Boston: Beacon Press.

Van Dommelen, P. (2011). Postcolonial archaeologies between discourse and practice. World Archaeology, 43(1), 1-6.

Weizman, E. (2012). Hollow land: Israel's architecture of occupation. London: Verso Books. Wynne-Jones, S. and Fleisher, J., 2015. Theory in Africa, Africa in Theory: Locating Meaning in Archaeology. London: Routledge.

Yeoh, B. (2001). Postcolonial cities. Progress in Human Geography, 25(3), 456-468.

Yeoh, B. (2003). Contesting space in colonial Singapore: Power relations and the urban built environment. Singapore: National University Singapore Press. 